Article

\title{
Non-Classical Transformation of Benzendiazonium Hydrogen Sulfates. Access to 1,3-Dimethylisochromeno[4,3-c]pyrazol- 5(1H)-one, a Potential Benzodiazepine Receptor Ligand
}

\author{
Benedetta Maggio, Demetrio Raffa *, Maria Valeria Raimondi and Giuseppe Daidone \\ Dipartimento di Scienze e Tecnologie Biologiche Chimiche e Farmaceutiche, \\ Università degli Studi di Palermo, Via Archirafi, 32, 90123-Palermo, Italy; \\ E-Mails: benedetta.maggio@unipa.it (B.M.); mariavaleria.raimondi@unipa.it (M.V.R.); \\ giuseppe.daidone@unipa.it (G.D.) \\ * Author to whom correspondence should be addressed; E-Mail: demetrio.raffa@unipa.it; \\ Tel.: +39-091-2389-1917.
}

Received: 13 September 2013; in revised form: 12 October 2013 / Accepted: 15 October 2013 / Published: 22 October 2013

\begin{abstract}
The compound 2-((1,3-dimethyl-1H-pyrazol-5-yl)(methyl)carbamoyl)benzenediazonium hydrogen sulfate (10) was reacted with copper sulfate and sodium chloride, in the presence of ascorbic acid as reducing agent, to afford a mixture of the chlorinated epimers 4'-chloro-2,2',5'-trimethyl-2',4'-dihydrospiro[isoindoline-1,3'-pyrazol]-3-one (18) and (19), the epimers 4'-hydroxy-2,2',5'-trimethyl-2',4'-dihydrospiro[isoindoline-1,3'pyrazol]-3-one (20) and (21), and $N$-(1,3-dimethyl-1H-pyrazol-5-yl)benzamide (22). Under the foregoing conditions, diazonium salt $\mathbf{1 0}$ affords neither the 2-chloro- $N$-(1,3-dimethyl$1 H$-pyrazol-5-yl)- $N$-methylbenzamide (23) nor the tricyclic derivative $\mathbf{2 4}$, the classical products of the Sandmeyer and Pschorr reactions, respectively. Finally, by heating 20 at $210{ }^{\circ} \mathrm{C}$ the compound 1,3-dimethylisochromeno[4,3-c]pyrazol-5(1H)-one (24) was obtained. The transformation under the above conditions of 2-((4-chloro-3-methyl-1-phenyl1H-pyrazol-5-yl)(methyl)carbamoyl)benzendiazonium hydrogen sulphate (11) afforded 4',4'-dichloro-2,5'-dimethyl-2'-phenyl-2',4'-dihydrospiro[isoindoline-1,3'-pyrazol]-3-one (29) as the sole reaction product.
\end{abstract}

Keywords: heterocycles; Pschorr reaction; Sandmeyer reaction; 1,5-hydrogen atom transfer; isochromeno[4,3-c]pyrazol-5(1H)-one 


\section{Introduction}

Previously we reported the transformation of diazonium hydrogen sulphate $\mathbf{2}$ derived from 2-amino- $N$-methyl- $N$-(3-methyl-1-phenyl-1 $H$-pyrazol-5-yl)benzamide (1). This reaction was carried out with $\mathrm{CuSO}_{4}$ and $\mathrm{NaCl}$, in the presence of ascorbic acid as a reducing agent [1] (Scheme 1). The above mixture was used earlier by Hanson and co-workers [2] to perform the Sandmeyer reaction on 4-chlorobenzendiazonium chloride in a homogeneous aqueous phase. Ascorbic acid reduces $\mathrm{Cu}(\mathrm{II})$ to $\mathrm{Cu}(\mathrm{I})$ which, in turn, reduces the diazonium ion to a diazenyl radical. The latter intermediate decomposes to dinitrogen and the phenyl radical. Copper(II) ions form complexes with chloride ions which are able to transfer a chloro radical to the 4-chlorophenyl by a ligand transfer process to afford 1,4-dichlorobenzene [2]. The diazonium hydrogen sulfate $\mathbf{2}$ afforded neither the chloro derivative $\mathbf{3}$, the product of the classical Sandmeyer reaction, nor the tricyclic derivative $\mathbf{9}$, the expected product of the competitive Pschorr ring closure, and instead we obtained epimers 7 and 8 [1].

Scheme 1. Transformation of the diazonium salt 2 by reaction with $\mathrm{CuSO}_{4} / \mathrm{NaCl} /$ ascorbic acid.<smiles>Cc1cc(NC(=O)c2ccccc2)n(P)n1</smiles><smiles>CC1=NN(C)[C@]2(c3ccccc3C(=O)N2C)[C@@H]1O</smiles>
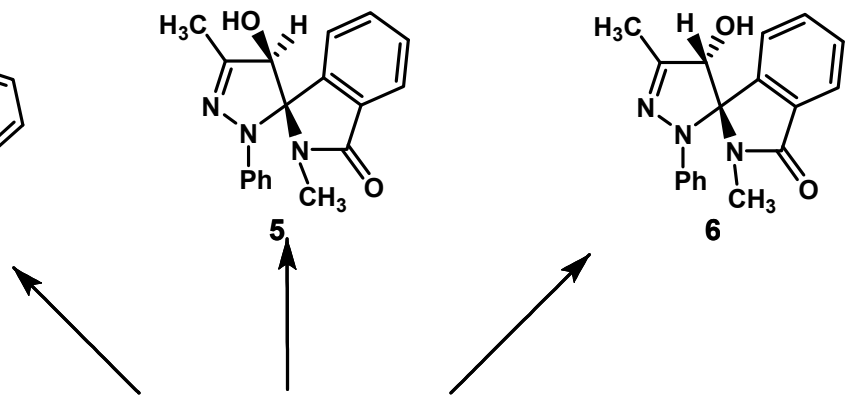

6<smiles>Cc1cc(N(C)C(=O)c2ccccc2N)n(-c2ccccc2)n1</smiles><smiles>CCC</smiles><smiles>Cc1cc(N(C)C(=O)c2ccccc2N(C)C)n(-c2ccccc2)n1</smiles>

$\mathrm{H}_{3} \mathrm{C}$<smiles>[Y]P([CH])n1cc(C)cc1N(C)C(=O)c1ccccc1Cl</smiles>

3

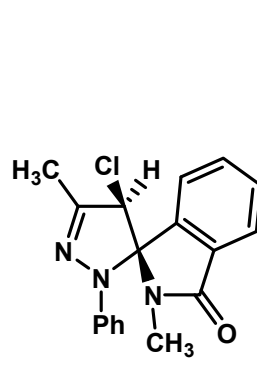

7
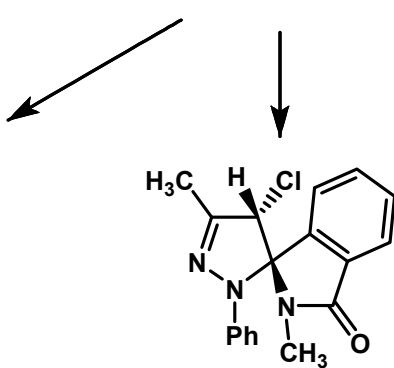

8

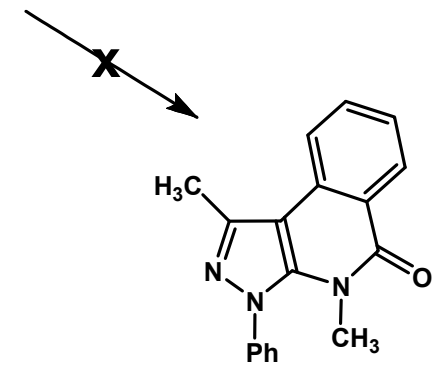

9

Recently a re-investigation of the transformation reaction of diazonium salt $\mathbf{2}$ in the presence of $\mathrm{CuSO}_{4} / \mathrm{NaCl} /$ ascorbic acid has allowed to establish that a demethylation process also takes place to give $N$-(3-methyl-1-phenyl-1H-pyrazol-5-yl)benzamide 4 (for the mechanism see Scheme 5, below). Moreover, trace amounts of the hydroxy spiro derivatives 5 and 6 [1] were detected by TLC analysis. In our continuing research on this reaction [1,3-5], we became interested in investigating the behaviour of substrates possessing an alkyl group, such as methyl, in lieu of the pyrazole N-phenyl, as well as a substituent at the 4-position of the pyrazole nucleus, in order to verify whether such modifications are able to influence the course of the reaction. In fact, phenyl and methyl groups exert 
different electronic as well as steric effects on the pyrazole ring. Moreover, electronic and steric effects engendered by the substituent at the 4-position of the pyrazole nucleus could also affect the reaction outcome. Here, we describe the $\mathrm{CuSO}_{4}$ /ascorbic acid-catalyzed decomposition in the presence of $\mathrm{NaCl}$ of the diazonium hydrogen sulfates $\mathbf{1 0}$ and $\mathbf{1 1}$ (Figure 1). These intermediates bear a methyl group or a chloro atom on the pyrazole nucleus, at positions 1 or 4 , respectively.

Figure 1. Diazonium hydrogen sulfates 2, 10 and 11.<smiles>Cc1cc(N(C)C(=O)c2ccccc2[N+](=O)[O-])n(-c2ccccc2)n1</smiles>

2<smiles>Cc1cc(N(C)C(=O)c2ccccc2[N+](=O)[O-])n(C)n1</smiles>

10<smiles>Cc1nn(-c2ccccc2)c(N(C)C(=O)c2ccccc2[N+](=O)[O-])c1Cl</smiles>

11

\section{Results and Discussion}

Benzendiazonium hydrogen sulfates derivatives $\mathbf{1 0}$ and $\mathbf{1 1}$ were prepared following Schemes 2 and 3.

Scheme 2. Preparation of the amino derivative $\mathbf{1 7}$ and its transformation.

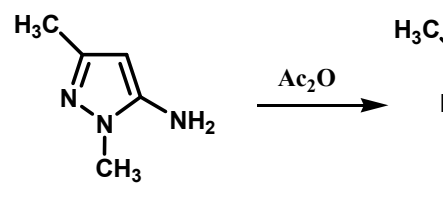

12<smiles>CC(=O)Nc1cc(C)nn1C</smiles>

13<smiles>CC(=O)N(C)c1cc(C)nn1C</smiles>

14<smiles>[Y]c1cccc(C(=O)N(C)c2cc(C)nn2C)c1Cl</smiles>

23<smiles>Cc1cc(N(C)C(=O)c2ccccc2[N+](=O)[O-])n(C)n1</smiles><smiles>CCCCCCCCCCCCCC(=O)Cl</smiles><smiles>CCCCCCCC</smiles><smiles>CNc1cc(C)nn1C</smiles>

15<smiles>Cc1cc(N(C)C(=O)c2ccccc2N=S(=O)(O)O)n(C)n1</smiles><smiles></smiles>

24 $\mathrm{CuSO}_{4} / \mathrm{NaCl} / \mathrm{Ascorbic}$ acid, r.t.<smiles>CC1=NN(C)[C@]2(c3ccccc3C(=O)N2C)C1Cl</smiles>

18,19

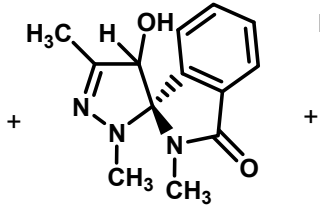

20,21<smiles>Cc1cc(NC(=O)c2ccccc2)n(C)n1</smiles>

22 
Scheme 3. Preparation of the amino derivative $\mathbf{2 8}$ and its transformation.

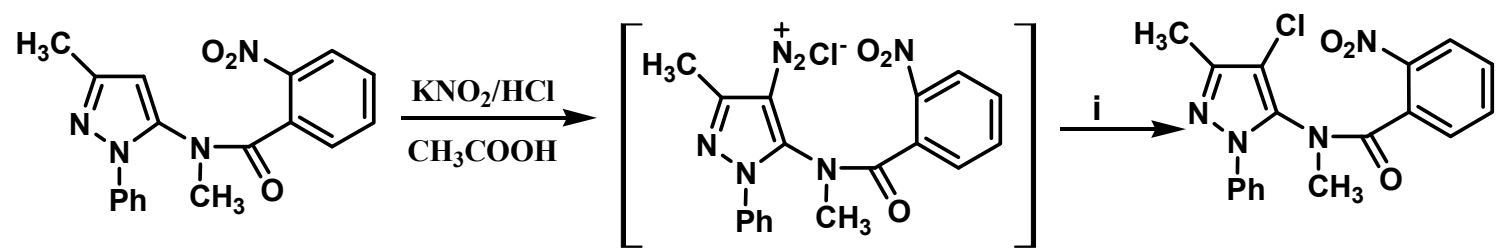

25

26

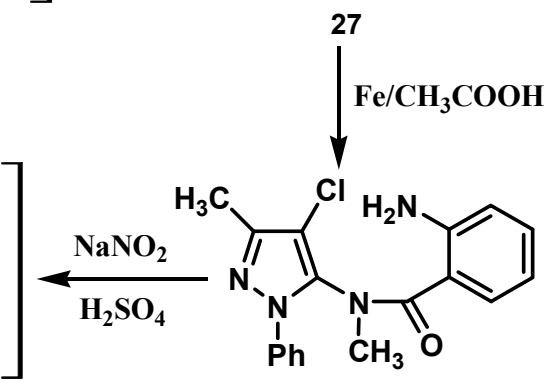

32

11

28

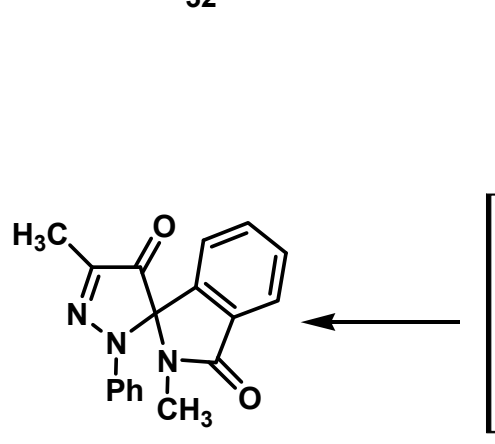

31

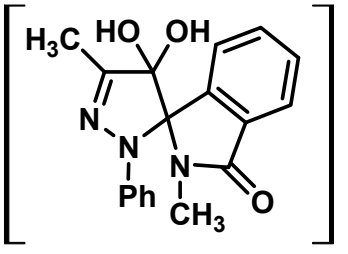

30

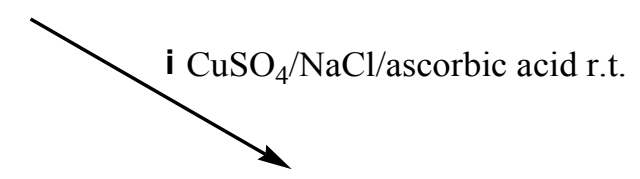

i $\mathrm{CuSO}_{4} / \mathrm{NaCl} /$ ascorbic acid r.t.

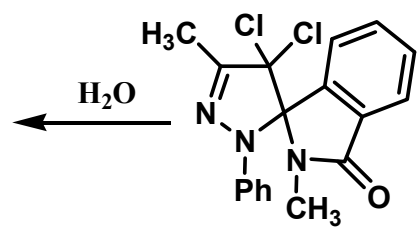

29

The amine 12 was reacted with acetic anhydride to give the acetamide derivative $\mathbf{1 3}$ which, in turn, was methylated with methyl iodide (Scheme 2). The obtained di-substituted acetamide derivative 14 was hydrolyzed with a potassium hydroxide ethanol-water solution to give the pyrazol-5-amine 15 .

Condensation of 15 with 2-nitrobenzoyl chloride afforded the 2-nitrobenzamide derivative $\mathbf{1 6}$ which was reduced with hydrogen in the presence of palladium/activated charcoal catalyst to give the 2-amino- $N$-methylbenzamide derivative 17 , diazotization of which produced the diazonium hydrogen sulfate 10. Exposure of $\mathbf{1 0}$ to $\mathrm{CuSO}_{4} / \mathrm{NaCl} /$ ascorbic acid, as seen earlier for $\mathbf{2}$, afforded a mixture of the chlorinated epimers $\left(1 S, 4^{\prime} R\right)$ - (or $\left(1 S, 4^{\prime} S\right)$-) and $\left(1 S, 4^{\prime} S\right)$ - (or $\left(1 S, 4^{\prime} R\right)$-) $\mathbf{1 8}$ and $\mathbf{1 9}$, respectively, and the hydroxyl epimers $\left(1 S, 4^{\prime} R\right)$ - (or $\left(1 S, 4^{\prime} S\right)$-) and $\left(1 S, 4^{\prime} S\right)$ - (or $\left(1 S, 4^{\prime} R\right)$-) 20 and $\mathbf{2 1}$, together obviously with the related enantiomers (not represented in the Schemes), and the benzamide derivative 22. Finally, no evidence was obtained for the formation of the chloro derivative $\mathbf{2 3}$, the product of the classical Sandmeyer reaction, as well as of 1,3,4-trimethylpyrazole[3,4-c]isoquinoline-5(4H)-one (24), the expected product of a possible competing Pschorr ring closure.

The preparation of substrate $\mathbf{1 1}$ started with the reaction of the 2-nitrobenzamide derivative $\mathbf{2 5}$ with a seven-fold excess of nitrous acid in acetic acid, resulting in the direct introduction of a diazo group at the 4-position of the pyrazole nucleus [6,7] (Scheme 3). The transformation in situ of the diazonium salt 26 into the chloro derivative 27 was performed with $\mathrm{CuSO}_{4}, \mathrm{NaCl}$ and ascorbic acid [1,2]. Compound 27 was then reduced with iron in acetic acid, and the aniline derivative $\mathbf{2 8}$ thus obtained was diazotized to furnish 11. 
The reaction of this diazonium salt under the same conditions employed earlier for $\mathbf{2}$ and $\mathbf{1 0}$ afforded the dichloro spiro derivative 29, as the sole product of reaction (Scheme 3). Compound 29 was then converted into dione derivative 31, possibly via intermediate 30, upon refluxing in water. The new compounds were characterized by means of analytical and spectral data. The relative configuration of the pyrazoline $\mathrm{C}\left(4^{\prime}\right)$-atom of the spiro-compounds 18-21 were not determined. The work up of the reaction mixture obtained by transformation of $\mathbf{1 0}$ did not allow us to isolate the epimers 18 and 19. The ${ }^{1} \mathrm{H}-\mathrm{NMR}$ spectrum of the obtained mixture showed singlets at 2.05, 2.07, 2.37, 2.44, 2.79 and $2.81 \mathrm{ppm}$, as well as at 5.54 and $5.83 \mathrm{ppm}$ (ratio 1:2.25), consistent with the methyls and the pyrazoline $\mathrm{H}-4$ of both epimers. On the contrary, epimers $\mathbf{2 0}$ and $\mathbf{2 1}$ were obtained as single compounds. The ${ }^{1} \mathrm{H}-\mathrm{NMR}$ spectrum of $\mathbf{2 0}$ showed three singlets at 1.94, 2.34 and $2.78 \mathrm{ppm}$, attributable to three methyls, and two doublets centered at 5.11 and $6.12 \mathrm{ppm}$ for the pyrazoline H-4 and $\mathrm{OH}-4$, respectively. Upon $\mathrm{D}_{2} \mathrm{O}$ exchange the $\mathrm{OH}$ signal in the the spectrum disappeared, and the $\mathrm{H}-4$ doublet collapsed to a singlet. The IR spectrum confirmed the presence of the pyrazoline hydroxyl by the absorption band at $3,263 \mathrm{~cm}^{-1}$. The epimer 21 produced very similar IR and ${ }^{1} \mathrm{H}-\mathrm{NMR}$ spectra. The analogous compounds 22 and $\mathbf{4}$ were identified by comparison of their physical and spectroscopic data with authentic specimens (see the Experimental Section).

As regards 29, the ${ }^{1} \mathrm{H}-\mathrm{NMR}$ spectrum showed signals at 2.38 and $2.66 \mathrm{ppm}$ for two methyls, as well as those in the range 6.70-7.96 ppm for nine aromatic protons. The assigned structure of compound 29 was confirmed by its ${ }^{13} \mathrm{C}$-NMR spectrum and by its chemical modification. In fact, the action of water on compound 29 afforded a product which was identical in all respects (mixed melting point, TLC, MS, IR) to dione derivative 31 [1].

Rationalization of the formation of 18, 19, 20, 21 and 4, 22 is outlined in the Schemes 4 and 5. Formation of the chloro epimers 18 and 19 from 10 takes place via the intermediates 33 and 34 (Scheme 4). The latter transforms to $\mathbf{1 8}$ and $\mathbf{1 9}$ by a chloro transfer process from copper(II)-chloro complexes [1,2]. As regards the hydroxy spiro epimers $\mathbf{2 0}$ and 21, they might be afforded by two different mechanisms: by transfer of $\mathrm{H}_{2} \mathrm{O}^{+}$from the hydratation shell of the aqueous copper(II)-complex [8] to radical spiro intermediate 34, or by nucleophilic replacement of the chloro atom in $\mathbf{1 8}$ and 19 by attack of a molecule of water. We noted that the chloro epimers 7, 8 (Scheme 1) and 18, 19 (Scheme 2) were obtained as precipitates from the solutions of diazonium salts $\mathbf{2}$ and $\mathbf{1 0}$ respectively, being the yield for $\mathbf{7 , 8}$ [1] quite higher than that of $\mathbf{1 8 , 1 9}$ (45\% versus $8 \%$ ). Moreover, extraction of the mother liquors of the above reaction mixtures of $\mathbf{2}$ and $\mathbf{1 0}$ allowed us to obtain hydroxy spiro epimers only in the case of $\mathbf{1 0}$ (that is $\mathbf{2 0}$ and 21, yield 7\%). Instead, only trace amounts of the hydroxy spiro epimers $\mathbf{5}, \mathbf{6}$ could be detected by TLC in the crude mixture of $7, \mathbf{8}$. We also observed that the mixture of $\mathbf{1 8}$ and $\mathbf{1 9}$ could be transformed in $\mathbf{2 0}$ and $\mathbf{2 1}$ when it was reacted with cold $\left(5^{\circ} \mathrm{C}\right) 0.09 \mathrm{M}$ sulfuric acid solution, where 18, 19 slowly dissolved, allowing the mixture to stand at r.t. for $1 \mathrm{~h}$, mimicking thus the $\mathrm{pH}$ conditions of the reaction medium in which $\mathbf{1 0}$ transformed. When the same experiment was performed with the mixture of $\mathbf{7}$ and $\mathbf{8}$ no dissolution of the epimers in the acidic medium was observed. The suspension was extracted with ethyl acetate, and TLC of the extract did not reveal any transformation to give $\mathbf{5}$ and 6. At this point we realized that the low yield for $\mathbf{1 8 , 1 9}$ is due to their solubility in the reaction medium, where they undergo a nucleophilic substitution by attack of a molecule of water to afford the hydroxy spiro epimers 20 and 21. Nevertheless, a radical transfer process of $\mathrm{H}_{2} \mathrm{O}^{+}$to the spiro intermediate $\mathbf{3 4}$ to give 20, 21 can't be ruled out (Scheme 4). 
Scheme 4. Suggested mechanism for the transformation of $\mathbf{1 0 .}$<smiles>Cc1cc(N(C)C(=O)c2ccccc2N=S(=O)([O-])O[Na])n(C)n1</smiles><smiles>Cc1cc(N(C)C(=O)c2ccccc2)n(C)n1</smiles>

33<smiles>CC1=NN(C)[C@@]2(C=C(I)c3ccccc32)N1C</smiles><smiles>CC1=NN(C)[C@]2(c3ccccc3C(=O)N2C)[C@H]1O</smiles>

20 (or 21)

21 (or 20)

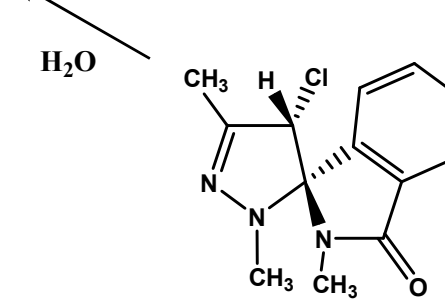

34<smiles>[3H][Te][TeH2]</smiles><smiles>CC1=NN(C)[C@]2(c3ccccc3C(=O)N2C)[C@H]1Cl</smiles>

18,19

The latter process can be invoked for the formation of the trace amounts of $\mathbf{5}$ and $\mathbf{6}$. Lastly, compounds 4 and 22 (Scheme 5) could be justified by considering a 1,5-hydrogen atom transfer process affording the radical intermediates $\mathbf{3 5 a}, \mathbf{b}$ which possibly undergo oxidation by cupric ions [9] to give carbocations $\mathbf{3 6 a}, \mathbf{b}$. The oxidation process would probably be favoured by the resonance stability of $\mathbf{3 6 a}, \mathbf{b}$, but the direct ligand radical transfer route from $\mathbf{3 5 a}, \mathbf{b}$ to $\mathbf{3 8 a}, \mathbf{b}$ cannot be ruled out. Intermediates 36a,b and 38a,b react with water affording the unstable compounds $\mathbf{3 7 a}, \mathbf{b}$ which by loss of formaldehyde transform into benzamide derivatives 22 and 4 , respectively.

Considering all the above data we concluded that the apparent different chemical behaviour between diazonium salts $\mathbf{2}$ and $\mathbf{1 0}$ is due to different solubilities of phenyl- and methyl-substituted chloro epimers, rather than to any electronic and steric effects of the $N$-phenyl- or $N$-methyl-pyrazole substituents.

As regards the transformation of the diazonium salt 11, performed under the identical conditions followed for the chemical analogues $\mathbf{1 0}$ and $\mathbf{2}$, the production of the dichloro spiro compound $\mathbf{2 9}$ was observed, which demonstrates that substitution at the 4-position of the pyrazoline nucleus does not hinder the ligand radical transfer process from the copper(II)-chloro complex to radical species 38 (Scheme 6). 
Scheme 5. 1,5-hydrogen atom transfer by -reaction in the transformation of diazonium salts 10, 2.

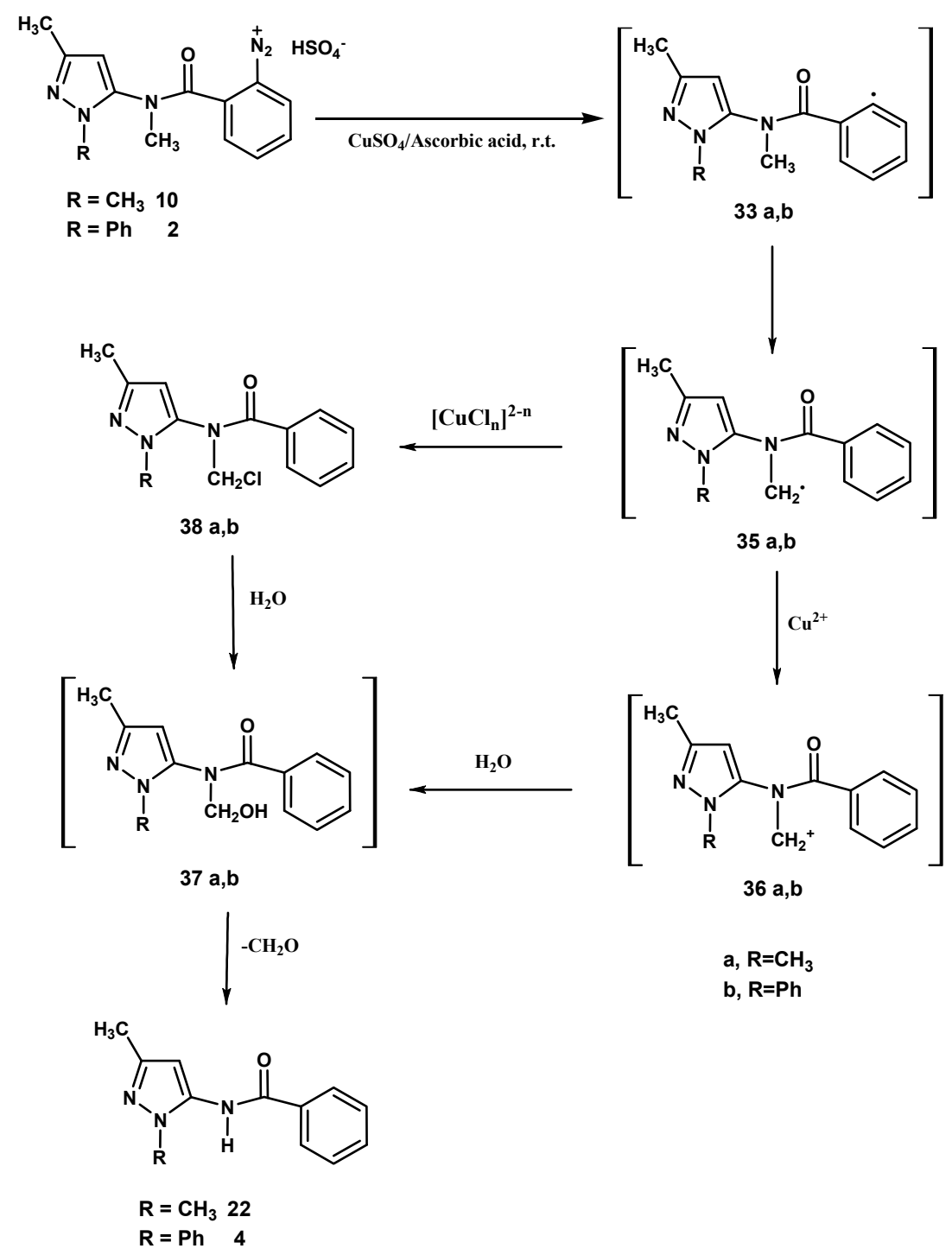

Scheme 6. Suggested mechanism for the transformation of $\mathbf{1 1 .}$

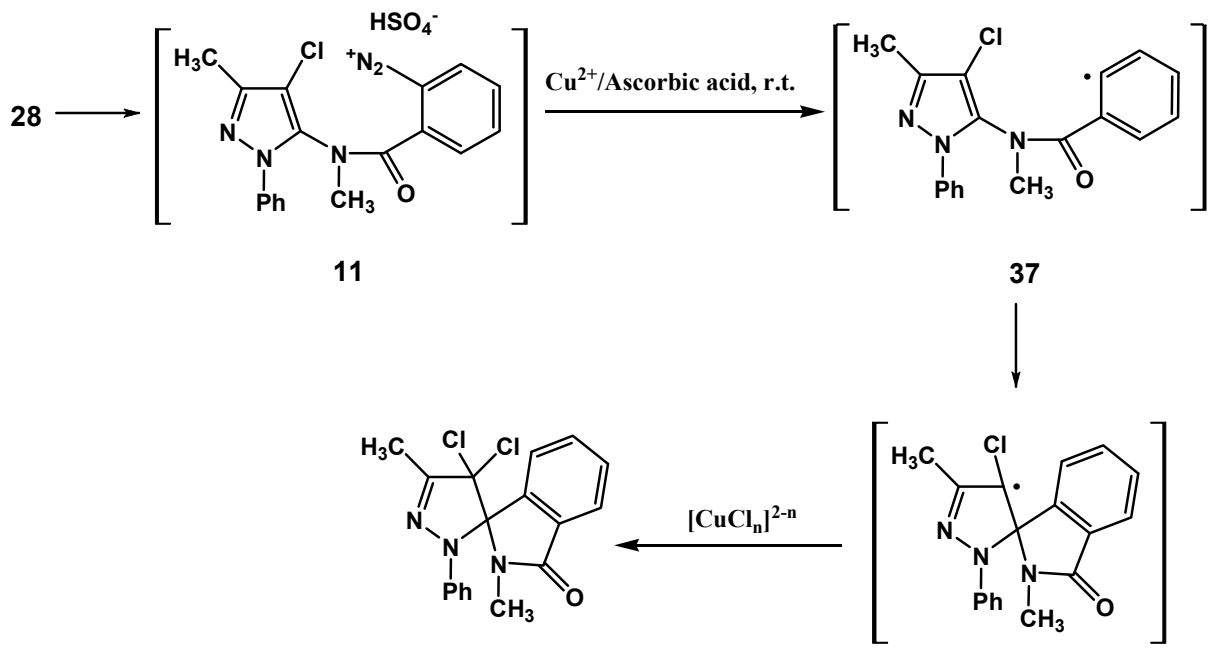

29 
The spiro compound $\mathbf{2 0}$ proved to be a useful intermediate since it was transformed by heating at $210^{\circ} \mathrm{C}$ into 1,3-dimethylisochromeno[4,3-c]pyrazol-5(1H)-one (39) (Scheme 7). The latter compound has the potential as a benzodiazepine receptor ligand. In fact, this compound shows two hydrogen bond acceptor atoms at the distance of about $3.5 \AA$, that is the isochromene oxygen and the nitrogen at position 2 of the pyrazole nucleus, which are mandatory in the molecule for a good affinity at the benzodiazepine binding site [10].

Scheme 7. Transformation of $\mathbf{2 0}$ by fusion.
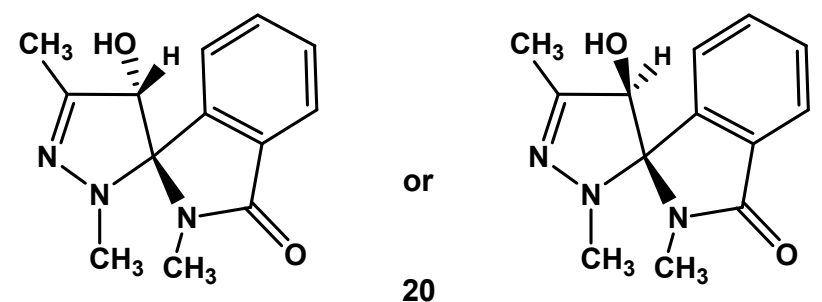

20

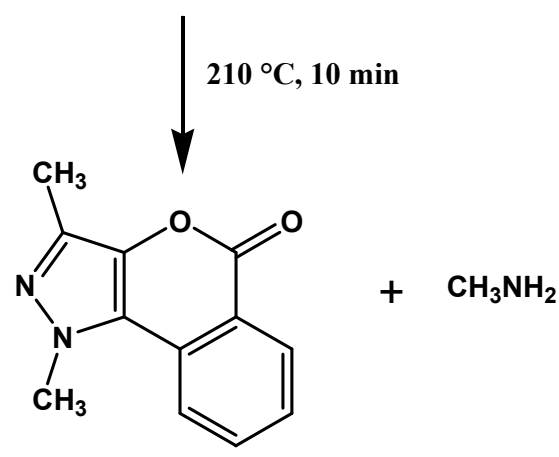

39

\section{Experimental}

\subsection{General}

Reaction progress was monitored by TLC on silica gel plates (Merck 60, $\mathrm{F}_{254}, 0.2 \mathrm{~mm}$ ). Organic solutions were dried over $\mathrm{Na}_{2} \mathrm{SO}_{4}$. Evaporation refers to the removal of solvent on a rotary evaporator under reduced pressure. All melting points were determined on a Büchi 530 capillary melting point apparatus and are uncorrected. IR spectra were recorded with a Perkin Elmer Spectrum RXI FT-IR System spectrophotometer as solid in $\mathrm{KBr}$ disc. ${ }^{1} \mathrm{H}-\mathrm{NMR}$ and ${ }^{13} \mathrm{C}-\mathrm{NMR}$ spectra were obtained in $\mathrm{CDCl}_{3}$ or DMSO- $d 6$ at 300.13 and $75.47 \mathrm{MHz}$ respectively, using a Bruker $\mathrm{AC}$ series $300 \mathrm{MHz}$ spectrometer (tetramethylsilane as an internal standard): chemical shifts are expressed in ppm values. Mass spectra at $70 \mathrm{eV}$ were obtained using an Autospec Ultima Ortogonal T.O.F.T. (Micromass) spectrometer. Merck silica gel (Kiesegel 60/230-400 mesh) was used for flash chromatography columns. Microanalyses data $(\mathrm{C}, \mathrm{H}, \mathrm{N})$ were obtained by an Elemental Vario EL. III apparatus and are within $\pm 0.4 \%$ of the theoretical values. Yields refer to products after one crystallization. The names of the compounds were obtained using the Chem Draw 9.0.1 software of Cambridge Soft (Cambridge MA, USA). 


\subsection{Preparation of N-(1,3-Dimethyl-1H-pyrazol-5-yl)acetamide (13)}

This compound was prepared following a literature method [11] modified by us: 1,3-dimethyl-1Hpyrazol-5-amine $(\mathbf{1 2}, 11.4 \mathrm{~g}, 0.102 \mathrm{~mol})$ was reacted under stirring at r.t. with acetic anhydride $(45 \mathrm{~mL})$ for $24 \mathrm{~h}$. After this time the solution was evaporated to give an oily residue which solidified when treated with triturated ice (20 g) and scraped. After filtration the material was air dried and crystallized from ethyl acetate/petroleum ether (b.p. $40-70{ }^{\circ} \mathrm{C}$ ) to give 13 in $70 \%$ yield; mp: $43-45^{\circ} \mathrm{C}$; $\mathrm{IR}\left(\mathrm{KBr}, \mathrm{cm}^{-1}\right)$ : 3,123 (broad, NH), 1,667 (CO); ${ }^{1} \mathrm{H}-\mathrm{NMR}$ (DMSO-d6, ppm): $2.04\left(3 \mathrm{H}, \mathrm{s}, \mathrm{CH}_{3}\right) ; 2.07\left(3 \mathrm{H}, \mathrm{s}, \mathrm{CH}_{3}\right)$; $3.55\left(3 \mathrm{H}, \mathrm{s}, \mathrm{CH}_{3}\right) ; 5.95(1 \mathrm{H}, \mathrm{s}$, pyrazole $\mathrm{H}-4) ; 9.84\left(1 \mathrm{H}\right.$, s, exchangeable with $\left.\mathrm{D}_{2} \mathrm{O}, \mathrm{NH}\right)$; Anal. Calcd. for $\mathrm{C}_{7} \mathrm{H}_{11} \mathrm{~N}_{3} \mathrm{O}(153.18)$ : C, 54.89\%; H, 7.24\%; N, 27.43\%. Found: C, 54.51\%; H, 6.86\%; N, 27.28\%.

\subsection{Preparation of N-(1,3-Dimehyl-1H-pyrazol-5-yl)-N-methylacetamide (14)}

To a solution of $N$-(1,3-dimethyl-1H-pyrazol-5-yl)acetamide $(13,1 \mathrm{~g}, 6.5 \mathrm{mmol})$ in hot acetone $(26 \mathrm{~mL})$ was added $\mathrm{KOH}(1.58 \mathrm{~g})$, and the mixture was refluxed for $10 \mathrm{~min}$. After this time $\mathrm{CH}_{3} \mathrm{I}(0.67$ $\mathrm{mL}, 10 \mathrm{mmol})$ in acetone $(4 \mathrm{~mL})$ was added and reflux was continued for one hour. The mixture was filtered, and evaporation of the filtrate afforded a residue which was treated with water $(20 \mathrm{~mL})$ and extracted with diethyl ether $(4 \times 20 \mathrm{~mL})$. The combined ether extracts were evaporated to give a solid residue which was crystallized from ethyl acetate affording compound $\mathbf{1 4}$ as colorless crystals in $46 \%$ yield, mp: $128-130{ }^{\circ} \mathrm{C}$. MS (m/z): $167\left(\mathrm{M}^{+}\right)$; IR ( $\left.\mathrm{KBr}, \mathrm{cm}^{-1}\right)$ : 1,681 (CO); ${ }^{1} \mathrm{H}-\mathrm{NMR}$ (DMSO-d6, ppm): $1.75\left(3 \mathrm{H}, \mathrm{s}, \mathrm{CH}_{3}\right) ; 2.12\left(3 \mathrm{H}, \mathrm{s}, \mathrm{CH}_{3}\right) ; 3.03\left(3 \mathrm{H}, \mathrm{s}, \mathrm{CH}_{3}\right) ; 3.57\left(3 \mathrm{H}, \mathrm{s}, \mathrm{CH}_{3}\right) ; 6.04(1 \mathrm{H}, \mathrm{s}$, pyrazole H-4). ${ }^{13} \mathrm{C}-\mathrm{NMR}$ (DMSO-d6) (ppm): $13.79\left(\mathrm{CH}_{3}\right), 21.39\left(\mathrm{CH}_{3}\right), 34.54\left(\mathrm{CH}_{3}\right), 35.39\left(\mathrm{CH}_{3}\right), 101.50(\mathrm{CH})$, 141.83 (C), 146.30 (C), 169.82 (CO); Anal. Calcd. for $\mathrm{C}_{8} \mathrm{H}_{13} \mathrm{~N}_{3} \mathrm{O}$ (167.21) : C, 57.46\%; H, 7.84\%; N, $25.13 \%$. Found: C, $57.21 \%$; H, 7.90\%; N, 24.76\%.

\subsection{Preparation of N,1,3-Trimethyl-1H-pyrazol-5-amine (15) [12]}

To a solution of $\mathrm{N}$-(1,3-dimethyl-1H-pyrazol-5-yl)- $N$-methylacetamide (14, $7.16 \mathrm{~g}, 42 \mathrm{mmol})$ in ethanol $(69 \mathrm{~mL})$ was added a $5 \mathrm{~N}$ aqueous solution of $\mathrm{KOH}(40 \mathrm{~mL})$, and the mixture was refluxed for $10 \mathrm{~h}$. After this time the reaction mixture was first filtered and then evaporated under vacuum to give a residue which was extracted with diethyl ether $(4 \times 90 \mathrm{~mL})$. The combined extracts were evaporated under reduced pressure and the obtained residue was processed by flash chromatography [13]: column external diameter $4 \mathrm{~cm}$, silica gel $0.040-0.063 \mathrm{~mm}$, ethyl acetate/acetone $(1: 1 \mathrm{v} / \mathrm{v})$ as eluent $(1.5 \mathrm{~L})$, fractions each $50 \mathrm{~mL}$. The first ten fractions were discarded, and fractions 11-25 were evaporated affording pure 15 as a pale yellow oil in $70 \%$ yield. IR $\left(\mathrm{KBr}, \mathrm{cm}^{-1}\right): 3,228(\mathrm{NH})$; ${ }^{1} \mathrm{H}-\mathrm{NMR}\left(\mathrm{CDCl}_{3}\right.$, ppm): $2.18\left(3 \mathrm{H}, \mathrm{s}, \mathrm{CH}_{3}\right), 2.80\left(3 \mathrm{H}, \mathrm{s}, \mathrm{CH}_{3}\right), 3.53\left(4 \mathrm{H}, \mathrm{s}, \mathrm{CH}_{3}, \mathrm{NH} ; 3 \mathrm{H}\right.$ after exchange with $\left.\mathrm{D}_{2} \mathrm{O}\right), 5.27$ (1H, s, pyrazole H-4); Anal. Calcd. for $\mathrm{C}_{6} \mathrm{H}_{11} \mathrm{~N}_{3}$ (125.17) : C, 57.57\%; H, 8.86\%; N, 33.57\%. Found: C, $57.21 \%$; H, 8.86\%; N, 33.53\%.

\subsection{Preparation of $N$-(1,3-dimethyl-1H-pyrazol-5-yl)-N-methyl-2-nitrobenzamide (16)}

A solution containing equimolar amounts $(6.16 \mathrm{mmol})$ of $N, 1,3$-trimethyl-1H-pyrazol-5-amine (15) and 2-nitrobenzoyl chloride in dry chloroform $(29 \mathrm{~mL})$ was refluxed for $5 \mathrm{~h}$. After the first hour triethylamine $(0.86 \mathrm{~mL})$ was added in four portions $(0.43 \mathrm{~mL} ; 0.21 \mathrm{~mL} ; 2 \times 0.11 \mathrm{~mL}$ respectively, with 
intervals of $1 \mathrm{~h}$ between additions). The solution was evaporated under reduced pressure, the residue washed with cold water and extracted with dichloromethane $(3 \times 50 \mathrm{~mL})$. The combined extracts were dried (sodium sulfate) and the solid residue afforded by evaporation was crystallized from ethyl acetate to give 16, as colorless crystals, in $64 \%$ yield, mp 132-133 ${ }^{\circ} \mathrm{C}$; $\mathrm{MS}(\mathrm{m} / \mathrm{z}) 274\left(\mathrm{M}^{+}\right)$; IR $\left(\mathrm{KBr}, \mathrm{cm}^{-1}\right)$ : 1,671 (CO); ${ }^{1} \mathrm{H}-\mathrm{NMR}\left(\mathrm{CDCl}_{3}, \mathrm{ppm}\right): 2.03\left(3 \mathrm{H}, \mathrm{s}, \mathrm{CH}_{3}\right), 3.40\left(3 \mathrm{H}, \mathrm{s}, \mathrm{CH}_{3}\right), 3.63\left(3 \mathrm{H}, \mathrm{s}, \mathrm{CH}_{3}\right), 5.70$ $(1 \mathrm{H}, \mathrm{s}$, pyrazole $\mathrm{H}-4), 7.29-8.30\left(4 \mathrm{H}\right.$, a set of signals, $\left.\mathrm{C}_{6} \mathrm{H}_{4}\right) ;{ }^{13} \mathrm{C}-\mathrm{NMR}$ (DMSO-d6, ppm): 13.92 $\left(\mathrm{CH}_{3}\right), 35.35\left(\mathrm{CH}_{3}\right), 36.36\left(\mathrm{CH}_{3}\right), 102.44(\mathrm{CH}), 124.80(\mathrm{CH}), 128.67(\mathrm{CH}), 131.09(\mathrm{CH}), 132.34(\mathrm{C})$, $134.96(\mathrm{CH}), 140.62(\mathrm{C}), 145.49(\mathrm{C}), 146.50(\mathrm{C}), 167.31(\mathrm{CO})$; Anal. Calcd. for $\mathrm{C}_{13} \mathrm{H}_{14} \mathrm{~N}_{4} \mathrm{O}_{3}(274.28)$ : C, 56.93\%; H, 5.14\%; N, 20.43\%. Found: C, 56.75\%; H, 5.13\%; N, 20.62\%.

\subsection{Preparation of 2-Amino-N-(1,3-Dimethyl-1H-pyrazol-5-yl)-N-methylbenzamide (17)}

To a solution of $N$-(1,3-dimethyl-1H-pyrazol-5-yl)- $N$-methyl-2-nitrobenzamide (16, $3.84 \mathrm{~g}, 14 \mathrm{mmol})$ in ethanol $(150 \mathrm{~mL})$ was added $10 \%$ palladium on activated charcoal catalyst $(380 \mathrm{mg})$. The mixture was reacted with hydrogen in a Parr apparatus at 50 psi for $20 \mathrm{~h}$. After this time the reaction mixture was filtered, and the filtrate was evaporated under vacuum to give an oily residue which was processed by Flash chromatography [13]: column external diameter $4.5 \mathrm{~cm}$, silica gel (0.040-0.063 mm), ethyl acetate as eluent $(1.8 \mathrm{~L})$, fractions each $50 \mathrm{~mL}$. The first 17 fractions were discarded. Fractions 18-21 were collected and evaporated under vacuum to afford $\mathbf{1 7}$ as a pale yellow pure oil in 44\% yield; MS $(\mathrm{m} / \mathrm{z}): 244\left(\mathrm{M}^{+}\right)$; IR $(\mathrm{KBr})\left(\mathrm{cm}^{-1}\right)$ : 3490-3200 (multiple bands, $\left.\mathrm{NH}_{2}\right), 1638(\mathrm{CO}) ;{ }^{1} \mathrm{H}-\mathrm{NMR}\left(\mathrm{CDCl}_{3}\right.$, ppm): $2.16\left(3 \mathrm{H}, \mathrm{s}, \mathrm{CH}_{3}\right), 3.34\left(3 \mathrm{H}, \mathrm{s}, \mathrm{CH}_{3}\right), 3.44\left(3 \mathrm{H}, \mathrm{s}, \mathrm{CH}_{3}\right), 4.81\left(2 \mathrm{H}, \mathrm{s}, \mathrm{NH}_{2}\right.$, exchangeable with $\left.\mathrm{D}_{2} \mathrm{O}\right), 5.87(1 \mathrm{H}$, s, pyrazole $\mathrm{H}-4), 6.40-7.07\left(4 \mathrm{H}\right.$, a set of signals, $\left.\mathrm{C}_{6} \mathrm{H}_{4}\right)$; Anal. Calcd. for $\mathrm{C}_{13} \mathrm{H}_{16} \mathrm{~N}_{4} \mathrm{O}$ (244.29) : C, 63.91\%; H, 6.60\%; N, 22.93\%. Found: C, 64.18\%; H, 6.63\%; N, 22.67\%.

\subsection{Preparation of 2-((1,3-Dimethyl-1H-pyrazol-5-yl)(methyl)carbamoyl)benzendiazonium hydrogen sulfate (10)}

The pulverized amine 17 (2.07 g, $8.48 \mathrm{mmol})$ was dissolved in cooled $\left(0-5{ }^{\circ} \mathrm{C}\right)$ aqueous sulfuric acid $(5 \mathrm{~N})(17 \mathrm{~mL})$, and aqueous sodium nitrite $(2.5 \mathrm{M})(3.5 \mathrm{~mL})$ was added dropwise to the stirred solution. The solution was stirred for a further $15 \mathrm{~min}$ in the ice bath and was then checked for excess nitrous acid with potassium iodide starch paper; the eventual excess can be destroyed by addition of urea. This solution was utilized in the next step.

\subsection{Transformation of the Diazonium Hydrogen Sulphate (10)}

To a cold $\left(0-5{ }^{\circ} \mathrm{C}\right)$ solution. $(400 \mathrm{~mL})$ of $\mathrm{CuSO}_{4} \cdot 5 \mathrm{H}_{2} \mathrm{O}(0.3 \mathrm{M})$ and $\mathrm{NaCl}(0.75 \mathrm{M})$, first the soln. of $\mathbf{1 0}$, obtained from the previous procedure, and then ascorbic acid $(370 \mathrm{mg}, 2.11 \mathrm{mmol})$ were added under stirring. The mixture was stirred for $1 \mathrm{~h}$ at r.t. and then filtered. The solid product obtained was washed with cold water, dried in desiccator (anhydrous $\mathrm{CaCl}_{2}, 24 \mathrm{~h}$ ) and then crystallized from diethyl ether to give the epimeric mixture of $\left(1 S, 4^{\prime} R\right)$ - (or $\left(1 S, 4^{\prime} S\right)$-) and $\left(1 S, 4^{\prime} S\right)$ - (or $\left(1 S, 4^{\prime} R\right)$-) $4^{\prime}$-chloro-2, $2^{\prime}, 5^{\prime}$ trimethy-2',4'-dihydrospiro[isoindoline-1,3'-pyrazol]-3-one (18) and $\mathbf{1 9}$, respectively in $8 \%$ overall yield; GLC-MS: two peaks, $228(\mathrm{~m} / \mathrm{z})$ for each, $\left(\mathrm{M}^{+}-\mathrm{Cl}\right)$; IR $\left(\mathrm{KBr}, \mathrm{cm}^{-1}\right)$ : $1,710(\mathrm{CO})$; ${ }^{1} \mathrm{H}-\mathrm{NMR}$ (DMSO-d6, ppm): $2.05\left(3 \mathrm{H}, \mathrm{s}, \mathrm{CH}_{3}\right), 2.07\left(3 \mathrm{H}, \mathrm{s}, \mathrm{CH}_{3}\right), 2.37\left(3 \mathrm{H}, \mathrm{s}, \mathrm{CH}_{3}\right), 2.44\left(3 \mathrm{H}, \mathrm{s}, \mathrm{CH}_{3}\right), 2.79$ 
$\left(3 \mathrm{H}, \mathrm{s}, \mathrm{CH}_{3}\right), 2.81\left(3 \mathrm{H}, \mathrm{s}, \mathrm{CH}_{3}\right), 5.54(1 \mathrm{H}, \mathrm{s}$, pyrazoline $\mathrm{H}-4) ; 5.83(1 \mathrm{H}, \mathrm{s}$, pyrazoline $\mathrm{H}-4)$; $7.59-7.77$ (2 $\times 4 \mathrm{H}$, a set of signals, $\left.2 \times \mathrm{C}_{6} \mathrm{H}_{4}\right)$; Anal. Calcd. for $\mathrm{C}_{13} \mathrm{H}_{14} \mathrm{ClN}_{3} \mathrm{O}(263.72): \mathrm{C}, 59.21 \% ; \mathrm{H}, 5.35 \% ; \mathrm{N}$, $15.93 \%$. Found: C, 59.28\%; H, 5.33\%; N, 15.93\%.

The mother liquors were saturated with $\mathrm{NaCl}$ and extracted with diethyl ether $(3 \times 100 \mathrm{~mL})$. The combined extracts were dried $\left(\mathrm{Na}_{2} \mathrm{SO}_{4}\right)$ and evaporated under reduced pressure. The oily residue $(850 \mathrm{mg})$ was chromatographed following the flash procedure [13]: external diameter of the column $4.5 \mathrm{~cm}$, silica gel $(0.040-0.063 \mathrm{~mm})$, ethyl acetate as eluent $(2 \mathrm{~L})$, fractions each $50 \mathrm{~mL}$. The initial seven fractions were discarded. Fractions 8 and 9 were evaporated under vacuum to give $130 \mathrm{mg}(7 \%)$ of pure $\left(1 S, 4^{\prime} R\right)$ - (or $\left(1 S, 4^{\prime} S\right)$-) $4^{\prime}$-hydroxy-2,2',5'-trimethyl-2',4'-dihydrospiro[isoindole-1,3'-pyrazol]$3(2 H)$-one (20) as a colourless solid, mp 160-163 ${ }^{\circ} \mathrm{C}$ (ethyl acetate); $\mathrm{MS}(\mathrm{m} / \mathrm{z}): 245\left(\mathrm{M}^{+}\right), 214$ $\left(\mathrm{M}^{+}-\mathrm{CH}_{3} \mathrm{NH}_{2}\right)$; IR(KBr, cm $\left.{ }^{-1}\right): 3,263(\mathrm{OH}), 1,671(\mathrm{CO}) ;{ }^{1} \mathrm{H}-\mathrm{NMR}$ (DMSO-d6, ppm): 1.94 (3H, s, $\left.\mathrm{CH}_{3}\right), 2.34\left(3 \mathrm{H}, \mathrm{s}, \mathrm{CH}_{3}\right), 2.78\left(3 \mathrm{H}, \mathrm{s}, \mathrm{CH}_{3}\right), 5.11(1 \mathrm{H}, \mathrm{d}, J=6.3 \mathrm{~Hz}$, pyrazoline $\mathrm{H}-4), 6.12(1 \mathrm{H}, \mathrm{d}$, $J=6.3 \mathrm{~Hz}, \mathrm{OH}$, exchangeable with $\left.\mathrm{D}_{2} \mathrm{O}\right), 7.52-7.70\left(4 \mathrm{H}\right.$, a set of signals, $\left.\mathrm{C}_{6} \mathrm{H}_{4}\right)$; Anal. Calcd. for $\mathrm{C}_{13} \mathrm{H}_{15} \mathrm{~N}_{3} \mathrm{O}_{2}$ (245.28): C, 63.66\%; H, 6.16\%; N, 17.13\%. Found: C, 63.42\%; H, 6.55\%; N, 17.02\%.

The combined fractions 11-14 when evaporated gave a residue (170 mg) which was chromatographed by preparative TLC on silica gel $(20 \times 20 \mathrm{~cm}$, thickness $2 \mathrm{~mm}$; ethyl acetate/chloroform 1:1 as eluent). The plate showed three bands (U.V. light at $254 \mathrm{~nm}$ ) among which the intermediate one underwent extraction with ethyl acetate. The extract was evaporated under vacuum and the residue obtained was crystallized to give a compound which was identical in all respects (mp, mixed mp, Rf, IR, ${ }^{1} \mathrm{H}-\mathrm{NMR}$ ) with an authentic specimen of $N$-(1,3-dimethyl-1H-pyrazol-5-yl)benzamide (22) [7], 2\% yield. The mother liquors from the crystallization of $\mathbf{2 2}$ were evaporated under vacuum, and the residue was processed by preparative TLC: $20 \times 20 \mathrm{~cm}$, thickness $2 \mathrm{~mm}$, ethyl acetate/chloroform 1:1 as eluent. The crude product obtained underwent the same procedure to give $10 \mathrm{mg}$ of pure $\left(1 S, 4^{\prime} S\right)$ (or $\left(1 S, 4^{\prime} R\right)$-) 4'-hydroxy-2,2',5'-trimethy-2',4'-dihydrospiro[isoindoline-1,3'-pyrazol]-3-one (21), as a colorless solid, mp 177-180 ${ }^{\circ} \mathrm{C}$; MS (m/z): $245\left(\mathrm{M}^{+}\right), 214\left(\mathrm{M}^{+}-\mathrm{CH}_{3} \mathrm{NH}_{2}\right) ;{ }^{1} \mathrm{H}-\mathrm{NMR}$ (DMSO-d6, ppm): $1.97\left(3 \mathrm{H}, \mathrm{s}, \mathrm{CH}_{3}\right), 2.22\left(3 \mathrm{H}, \mathrm{s}, \mathrm{CH}_{3}\right), 2.85\left(3 \mathrm{H}, \mathrm{s}, \mathrm{CH}_{3}\right), 4.92(1 \mathrm{H}, \mathrm{d}, J=5.7 \mathrm{~Hz}$, pyrazoline $\mathrm{H}-4), 5.85$ $\left(1 \mathrm{H}, \mathrm{d}, J=6.3 \mathrm{~Hz}\right.$, pyrazoline $\mathrm{OH}-4$, exchangeable with $\left.\mathrm{D}_{2} \mathrm{O}\right), 7.43-7.70\left(4 \mathrm{H}\right.$, a set of signals, $\left.\mathrm{C}_{6} \mathrm{H}_{4}\right)$; ${ }^{13} \mathrm{C}-\mathrm{NMR}$ (DMSO-d6, ppm): $12.75\left(\mathrm{CH}_{3}\right), 24.74\left(\mathrm{CH}_{3}\right), 34.02\left(\mathrm{CH}_{3}\right), 77.76(\mathrm{CH}), 91.86(\mathrm{C}), 111.21$ (C), $122.10(\mathrm{CH}), 124.65(\mathrm{CH}), 128.83(\mathrm{CH}), 130.45(\mathrm{CH}), 131.52(\mathrm{C}), 139.47(\mathrm{C}), 152.38(\mathrm{C}), 166.02$ (CO); Anal. Calcd. for $\mathrm{C}_{13} \mathrm{H}_{15} \mathrm{~N}_{3} \mathrm{O}_{2}(245.28)$ : C, 63.66\%; $\mathrm{H}, 6.16 \%$;, $17.13 \%$. Found: $\mathrm{C}, 63.45 \%$; $\mathrm{H}$, $6.17 \% ; \mathrm{N}, 17.20 \%$.

\subsection{Preparation of 1,3-Dimethylisochromeno[4,3-c]pyrazol-5(1H)-one (39)}

Compound $20(30 \mathrm{mg})$ was melted at $210{ }^{\circ} \mathrm{C}$ for $10 \mathrm{~min}$. The obtained material was crystallized from ethanol to give 39, as colorless solid, in $69 \%$ yield, mp $237-239{ }^{\circ} \mathrm{C}$; MS $(\mathrm{m} / \mathrm{z}): 214\left(\mathrm{M}^{+}\right)$; IR $\left(\mathrm{KBr}, \mathrm{cm}^{-1}\right): 1715(\mathrm{CO}) ;{ }^{1} \mathrm{H}-\mathrm{NMR}\left(\mathrm{CDCl}_{3}, \mathrm{ppm}\right): 2.37\left(3 \mathrm{H}, \mathrm{s}, \mathrm{CH}_{3}\right), 4.23\left(3 \mathrm{H}, \mathrm{s}, \mathrm{CH}_{3}\right), 7.55-8.46(4 \mathrm{H}$, a set of signals, $\left.\mathrm{C}_{6} \mathrm{H}_{4}\right) ;{ }^{13} \mathrm{C}-\mathrm{NMR}\left(\mathrm{CDCl}_{3}, \mathrm{ppm}\right)$ : $9.96\left(\mathrm{CH}_{3}\right), 40.07\left(\mathrm{CH}_{3}\right), 119.86(\mathrm{C}), 120.47(\mathrm{CH})$, $122.41(\mathrm{C}), 128.10(\mathrm{CH}), 128.58(\mathrm{C}), 132.47(\mathrm{CH}), 132.91(\mathrm{C}), 134.97(\mathrm{CH}), 136.95(\mathrm{C}), 162.08(\mathrm{CO})$; Anal. Calcd. for $\mathrm{C}_{12} \mathrm{H}_{10} \mathrm{~N}_{2} \mathrm{O}_{2}$ (214.22) : C, 67.28\%; H, 4.71\%; N, 13.08\%. Found: C, 67.56\%; H, $4.87 \%$;, $13.09 \%$. 


\subsection{Preparation of N-(3-Methyl-1-phenyl-1H-pyrazol-5-yl)benzamide (4)}

From the transformation of the diazonium salt 2 by the $\mathrm{CuSO}_{4} / \mathrm{NaCl} /$ ascorbic acid reagent combination: the diazonium hydrogen sulfate 2 derived from compound 1 [1] (5.9 mmol) was decomposed following the procedure used for 10. The suspension obtained was filtered, and the solid was crystallized from ethanol $(95 \% \mathrm{~V} / \mathrm{V})$ to give epimers $7, \mathbf{8}$. The mother liquors when evaporated leave a residue $(350 \mathrm{mg}$ ) which was processed by preparative TLC (two plates, $20 \times 20 \mathrm{~cm}$, thickness $2 \mathrm{~mm}$, ethyl acetate/petroleum ether 3:7 as eluent). Work up allowed us to obtain a product (140 $\mathrm{mg})$ which was identical in all respects (mp, mixed mp, IR, ${ }^{1} \mathrm{H}-\mathrm{NMR}$ ) to an authentic specimen of compound 4 [7]. The aqueous mother liquors were saturated with sodium chloride and extracted with ethyl acetate $(4 \times 150 \mathrm{~mL})$. The combined extracts were evaporated to give a residue $(70 \mathrm{mg}) \mathrm{which}$ was processed by preparative TLC. More of compound $4(20 \mathrm{mg})$ was obtained following the above procedure, overall yield $10 \%$.

\subsection{Preparation of N-(4-Chloro-3-methyl-1-phenyl-1H-pyrazol-5-yl)-N-methyl-2-nitrobenzamide (27)}

This compound was prepared by modifying the procedure reported in reference [14]. Compound 25 [15] (2 g, $5.95 \mathrm{mmol})$ was dissolved in acetic acid $(57 \mathrm{~mL})$ and then concentrated hydrochloric acid $(36.5 \% \mathrm{w} / \mathrm{w}, 4.3 \mathrm{~mL})$ was added. To the stirred solution a potassium nitrite aqueous solution $(3.5 \mathrm{~g}$ of $\mathrm{KNO}_{2}$ in $1.8 \mathrm{~mL}$ of $\mathrm{H}_{2} \mathrm{O}$ ) was added dropwise and stirring was continued for a further $24 \mathrm{~h}$. The obtained suspension was filtered and the filtrate was treated first with an aqueous solution $(300 \mathrm{~mL})$ of hydrochloric acid $(0.24 \mathrm{M})$, copper sulphate pentahydrate $(0.3 \mathrm{M})$ and sodium chloride $(0.75 \mathrm{M})$ and then with ascorbic acid $(260 \mathrm{mg}, 1.48 \mathrm{mmol})$. The mixture was stirred for $1 \mathrm{~h}$ at r.t. and then filtered. The solid product obtained was crystallized from ethanol $(95 \% \mathrm{~V} / \mathrm{V})$ to give 27 (yield $60 \%$ ) identical in all respects (mixed melting point, TLC, MS, IR) to an authentic specimen of compound 27 [14].

\subsection{Preparation of 2-Amino-N-(4-chloro-3-methyl-1-phenyl-1H-pyrazol-5-yl)-N-methylbenzamide (28)}

A suspension of Fe filings $(12.41 \mathrm{~g})$ in $5 \%(\mathrm{~V} / \mathrm{V})$ aqueous $\mathrm{AcOH}(16 \mathrm{~mL})$ was heated about $100{ }^{\circ} \mathrm{C}$ under stirring on the water bath of a rotavapor until $\mathrm{H}_{2}$ evolution ceased. The nitro derivative $27(6.9 \mathrm{~g}$, $18.5 \mathrm{mmol}$ ) was added in four portions, with intervals of $20 \mathrm{~min}$. between additions. After the last addition, stirring was continued at $100{ }^{\circ} \mathrm{C}$ for $1 \mathrm{~h}$, then the mixture was cooled to r.t. The $\mathrm{pH}$ of the suspension was adjusted to 7-8 with a saturated $\mathrm{NaHCO}_{3}$ solution. The solid was separated by filtration, air dried overnight, and then extracted with boiling $\mathrm{CHCl}_{3}(3 \times 30 \mathrm{~mL})$. The combined extracts were evaporated under vacuum, leaving an residue which was crystallized from ethyl acetate to give 28 in $80 \%$ yield, mp $165-166{ }^{\circ} \mathrm{C}$; MS $(\mathrm{m} / \mathrm{z}): 342\left(\mathrm{M}^{+}\right)$; IR $\left(\mathrm{cm}^{-1}\right)$ : 3485, $3358\left(\mathrm{NH}_{2}\right), 1640(\mathrm{CO})$; ${ }^{1} \mathrm{H}-\mathrm{NMR}(\mathrm{ppm}): 2.26(3 \mathrm{H}, \mathrm{s}, \mathrm{Me}), 3.40(3 \mathrm{H}, \mathrm{s}, \mathrm{Me}) ; 4.33\left(2 \mathrm{H}, \mathrm{s}\right.$, exchangeable with $\left.\mathrm{D}_{2} \mathrm{O}, \mathrm{NH}_{2}\right)$, 6.40-7.35 (9H, m, $\mathrm{C}_{6} \mathrm{H}_{5}$ and $\left.\mathrm{C}_{6} \mathrm{H}_{4}\right)$; Anal. Calcd. for $\mathrm{C}_{18} \mathrm{H}_{17} \mathrm{ClN}_{4} \mathrm{O}(340.81)$ : C, 63.44\%; H, 5.03\%; N, $16.44 \%$. Found: C, $63.35 \%$; H, 5.21\%; N, 16.56\%. 


\subsection{Preparation of 2-((4-Chloro-3-methyl-1-phenyl-1H-pyrazol-5-yl)(methyl)carbamoyl)benzendiazonium Hydrogen sulphate (11)}

The pulverized amine $28(1.5 \mathrm{~g}, 4.41 \mathrm{mmol})$ was dissolved in cooled $\left(0-5{ }^{\circ} \mathrm{C}\right)$ aqueous sulfuric acid $(10 \mathrm{M})(17.6 \mathrm{~mL})$ and aqueous sodium nitrite $(2.5 \mathrm{M})(1.82 \mathrm{~mL})$ was added drop-wise to the stirred solution. The solution was stirred for a further $15 \mathrm{~min}$ in the ice bath and was then checked for excess nitrous acid with potassium iodide starch paper. The eventual excess can be destroyed by addition of urea.

\subsection{Decomposition of the Diazonium Hydrogen Sulphate 11}

To a cold $\left(0-5{ }^{\circ} \mathrm{C}\right)$ soln. $(220 \mathrm{~mL})$ of $\mathrm{CuSO}_{4} \cdot 5 \mathrm{H}_{2} \mathrm{O}(0.3 \mathrm{M})$ and $\mathrm{NaCl}(0.75 \mathrm{M})$, first the soln. of 11 obtained from the previous procedure, and then ascorbic acid $(195 \mathrm{mg}, 1.11 \mathrm{mmol})$ were added under stirring. The mixture was stirred for $1 \mathrm{~h}$ at r.t. and then filtered. The solid product obtained was dried in desiccator (anhydrous $\mathrm{CaCl}_{2}$ ) for $24 \mathrm{~h}$ and then crystallized from ethyl acetate to give compound 29 in 80\% yield, mp 202-203 ${ }^{\circ} \mathrm{C}$; MS $(\mathrm{m} / \mathrm{z}): 359\left(\mathrm{M}^{+}\right)$; IR $\left(\mathrm{cm}^{-1}\right): 1713(\mathrm{CO}) ;{ }^{1} \mathrm{H}-\mathrm{NMR}\left(\mathrm{CDCl}_{3}, \mathrm{ppm}\right): 2.38$ $(3 \mathrm{H}, \mathrm{s}, \mathrm{Me}), 2.66(3 \mathrm{H}, \mathrm{s}, \mathrm{Me}), 6.70-7.96\left(9 \mathrm{H}, \mathrm{m}, \mathrm{C}_{6} \mathrm{H}_{5}\right.$ and $\left.\mathrm{C}_{6} \mathrm{H}_{4}\right) ;{ }^{13} \mathrm{C}-\mathrm{NMR}\left(\mathrm{CDCl}_{3}, \mathrm{ppm}\right): 11.13$ $\left(\mathrm{CH}_{3}\right), 26.64\left(\mathrm{CH}_{3}\right), 96.61(\mathrm{C}), 93.23(\mathrm{C}), 115.59(2 \mathrm{xCH}), 122.45(\mathrm{CH}), 124.30(\mathrm{CH}), 127.21(\mathrm{CH})$, $129.05(2 \times C H), 130.98(\mathrm{CH}), 131.62(\mathrm{CH}), 132,66(\mathrm{C}), 139.08(\mathrm{C}), 142.21(\mathrm{C}), 147(\mathrm{C}), 167(\mathrm{CO})$; Anal. Calcd. for $\mathrm{C}_{18} \mathrm{H}_{15} \mathrm{Cl}_{2} \mathrm{~N}_{3} \mathrm{O}$ (359.06) : C, 60.01\%; H, 4.20\%; N, 11.66\%. Found: C, 60.20\%; H, $4.58 \%$; N $11.69 \%$.

3.15. Reaction of 4',4'-Dichloro-2,5'-dimethyl-2'-phenyl-2',4'-dihydrospiro[isoindoline-1,3'-pyrazol]3-one (29) with Water

To a solution of $29(10 \mathrm{mg})$ in acetonitrile $(1 \mathrm{~mL})$ was added water $(1 \mathrm{~mL})$ and the mixture was refluxed for $30 \mathrm{~min}$. The solution was evaporated under vacuum to give a pure residue which was identical in all respects to an authentic specimen of compound $\mathbf{3 1}$ [1].

\section{Conclusions}

The diazonium salts $\mathbf{2}$ and $\mathbf{1 0}$ show as unique structural diversity the different substituent at the 1-position of the pyrazole nucleus, that is phenyl or methyl. The above diversity does not lead to a different chemical reactivity of these diazonium salts when they are reacted with the reagents copper sulphate/ascorbic acid/sodium chloride. In fact, the observed difference in the composition of the reaction mixtures of $\mathbf{1 0}$ and $\mathbf{2}$ is not due to different electronic and/or steric effects of the pyrazole substituents at 1-position, but rather to a remarkable differential solubility between the pairs of epimers 18, 19 and 7, 8. Epimers 18, 19 partially dissolve in the reaction mixture and undergo nucleophilic replacement of the chloro atom to give the hydroxy spiro derivatives $\mathbf{2 0 , 2 1}$, whereas epimers $\mathbf{7 , 8}$ do not follow this pathway. As regards diazonium salt 11, the presence of a substituent at the 4-position of the pyrazole moiety does not hinder this position, and a dichloro spiro derivative $\mathbf{2 9}$ is obtained. 


\section{Supplementary Materials}

${ }^{1} \mathrm{H}-\mathrm{NMR}$ and ${ }^{13} \mathrm{C}-\mathrm{NMR}$ of compounds 17, 18, 19 (mixture), 20, 21, 28, 29 and 39. These materials can be accessed at: http://www.mdpi.com/1420-3049/18/10/13096/s1.

\section{Acknowledgments}

Financial support from "Fondo di Finanziamento della Ricerca dell'Ateneo di Palermo (ex 60\%)" is gratefully acknowledged.

\section{Conflicts of Interest}

The authors declare no conflict of interest.

\section{References}

1. Daidone, G.; Maggio, B.; Raffa, D.; Plescia, S.; Benetollo, F.; Bombieri, G. Consecutive Pschorr-Sandmeyer reactions in a pyrazole series. Part 2. ${ }^{1}$ Access to the [2]benzopyrano[4,3c]pyrazole system of pharmaceutical interest. J. Chem. Soc. Perkin Trans. I 1998, 1988, 2891-2898.

2. Hanson, P.; Jones, J.R.; Gilbert, B.C.; Timms, A.W. Sandmeyer reactions. Part 1. A comparative study of the transfer of halide and water ligands from complexes of $\mathrm{Cu}^{\mathrm{II}}$ to aryl radicals. J. Chem. Soc. Perkin. Trans. II 1991, 1991, 1009-1017.

3. Daidone, G.; Plescia, S.; Maggio, B.; Sprio, V.; Benetollo, F.; Bombieri, G. Modifications and extensions of the Pschorr reaction in pyrazole series. Access to the [2]benzopyrano[4,3-c]pyrazole system of pharmaceutical interest. J. Chem. Soc. Perkin Trans. I 1993, 1993, 285-291.

4. Maggio, B.; Daidone, G.; Raffa, D.; Plescia, S.; Bombieri, G.; Meneghetti, F. Nonclassical Pschorr and Sandmeyer Reactions in Pyrazole Series. Helv. Chim. Acta 2005, 88, 2272-2281.

5. Maggio, B.; Raffa, D.; Raimondi, M.V.; Cascioferro, S.; Plescia, S.; Sabatino, M.A.; Bombieri, G.; Meneghetti, F.; Daidone, G. Comparative studies of the Pschorr reaction in the pyrazole series. Access to the new dibenzo $[e, g]$ pyrazolo $[1,5-a][1,3]$ diazocine system of pharmaceutical interest. Arkivoc 2008, 16, 130-143.

6. Fusco, R. Heterocyclic Compounds: Pyrazoles, Pyrazolines, Pyrazolidines, and Condensed Rings; Wiley, R.H., Behr, L.C., Eds.; Interscience Publishers: New York, NY, USA, 1967; p. 105.

7. Daidone, G.; Bajardi, M.L.; Plescia, S.; Raffa, D.; Schillaci, D.; Maggio, B.; Benetollo, F.; Bombieri, G. One-step synthesis, crystallographic studies and antimicrobial activity of new 4-diazopyrazole derivatives. Eur. J. Med. Chem. 1996, 31, 461-468.

8. Lewin, A.H.; Cohen, T. Mechanism of the copper induced Pschorr cyclization. New phenol synthesis involving hydroxylation of the intermediate radical by cupric ion. J. Org. Chem. 1967, 32, 3844-3850.

9. Lewin, A.H.; Dinwoodie, A.H.; Cohen T. 1,5-hydrogen transfer during diazonium ion decomposition-IV: The copper catalyzed reaction. A Case of hydrogen atom or hydride ion transfer in the same system. Tetrahedron 1966, 22, 1527-1537. 
10. Maggio, B.; Raffa, D.; Raimondi, M.V.; Plescia, F.; Trincavelli, M.L.; Martini, C.; Meneghetti, F.; Basile, L.; Guccione, S.; Daidone, G. Synthesis, benzodiazepine receptor binding and molecular modelling of isochromeno[4,3-c]pyrazol-5(1H)-one derivatives. Eur. J. Med. Chem. 2012, 54, 709-720.

11. Vicentini, C.B.; Veronese, A.C.; Giori, P.; Lumachi, B.; Guarneri, M. A new general and efficient synthesis of imidazo[4,5-c]pyrazole derivatives. Tetrahedron 1990, 46, 5777-5788.

12. Migliara, O.; Flugy, A.; Novara, V.; Gagliano, M. Synthesis and pharmacological evaluation of some pyrazolo [3,4-e][1,4] diazepin-4,7-diones. Farmaco 1992, 47, 111-119.

13. Still, W.C.; Kahn, M.; Mitra, A. Rapid chromatographic technique for preparative separations with moderate resolution. J. Org. Chem. 1978, 43, 2923.

14. Daidone, G.; Plescia, S.; Raffa, D.; Maggio, B.; Schillaci, D. Synthesis and Evaluation of antimicrobial Activity of New 4-Nitroso and 4-Diazopyrazole Derivatives. Farmaco 1992, 47 , 203-217.

15. Plescia, S.; Daidone, G.; Sprio, V.; Aiello, E.; Dattolo, G.; Cirrincione, G. Studies on the synthesis of heterocyclic compounds. Part I. The pschorr reaction in the pyrazole series. J. Heterocycl. Chem. 1978, 15, 1287-1290.

Sample Availability: Samples of the compounds 18, 19 (mixture), 20, 22, 39, 16, 17, 4 are available from the authors.

(C) 2013 by the authors; licensee MDPI, Basel, Switzerland. This article is an open access article distributed under the terms and conditions of the Creative Commons Attribution license (http://creativecommons.org/licenses/by/3.0/). 